\title{
Past antihypertensive drugs, obesity, daily light working load and risk of hypertension: An Indonesian 2001 rural study
}

\author{
Bastaman Basuki", Dewi Sumaryani Soemarko", Zarni Amri*, Ermita Isfandiary Ibrahim ${ }^{\dagger}$
}

\begin{abstract}
Abstrak
Penelitian mengenai faktor risiko yang berkaitan dengan hipertensi di daerah pedesaan masih belum banyak dilakukan, dan penelitian ini bertujuan untuk mengidentifikasi lebih lanjut faktor risiko yang berkaitan dengan hipertensi di antara penduduk pedesaan. Data berasal dari data hasil pengalaman lapangan mahasiswa tingkat 2 Fakultas Kedokteran Universitas Indonesia tanggal 27 Juni 2001 di pedesaan yang berbukit-bukit di Kecamatan Cijeruk, Bogor. Subjek dipilih secara random dengan memakai klaster rukun tetangga yang berbeda dengan sampel penelitian tahun lalu. Wawancara dan pengukuran tekanan darah dilakukan di rumah subjek penelitian pada pukul 1:00 sampai 4:00 petang. Hasil penelitian menunjukkan bahwa penduduk berumur 40 tahun atau lebih mempunyai risiko yang lebih tinggi untuk menderita hipertensi dibandingkan dengan penduduk yang berumur 18-39 tahun. Peningkatan risiko sangat mencolok di antara penduduk yang berumur 55-59 tahun [rasio odds (OR) suaian=17,73; 95\% interval kepercayaan $(C I)=6,26-50,27]$. Jika dibandingkan dengan orang berpostur tubuh normal, orang yang gemuk mempunyai risiko hipertensi lebih dari hampir dua kali lipat (OR suaian $=0,87 ; 95 \% C I=0,87-4,17 ; P=0,109)$. Menurut putus minum obat antihipertensi, subjek yang putus obat hipertensi mempunyai risiko hampir 14 kali lipat untuk menderita hipertensi. Akan tetapi, orang dengan beban kerja harian yang berat lebih terlidung terhadap hipertensi. Dapat disimpulkan bahwa hasil penelitian ini pada umumnya sama dengan hasil penelitian tahun lalu di tempat yang sama dengan subjek penelitian yang berbeda. Orang berumur lebih dari 40 tahun, yang putus pengobatan antihipertensi, dan orang yang tidak mempunyai beban kerja berat perlu mendapat perhatian terhadap kemungkinan menderita hipertensi. (Med J Indones 2001; 10: 224-9)
\end{abstract}

\begin{abstract}
This study aims to identify some risk factors related to hypertension in rural areas. The data for this study is a part of the result of the field study done by the second year medical students of the Faculty of Medicine, University of Indonesia, Jakarta, on June 27 th , 2001, at Cijeruk subdistrict in Bogor regency. The subjects were selected randomly using neighborhood cluster which was different from the previous study in 2000. Interviews and blood pressure were taken at the houses of the subjects from 1:00 PM to 4:00 PM. The results of this study showed that people aged 40 years or over had an increase risk to suffer hypertension compared to the 18-39 year old group, and the risk was most prominent among the 55-59 year group ladjusted odds ratio $(O R)=17.73 ; 95 \%$ confidence intervals $(C I)=6.26-50.271$. Compared to the subjects with normal body posture, those who were obese had more than two-fold increase in the risk to be hypertensive (adjusted $O R=0.87 ; 95 \% C I=0.87-4.17 ; P=0.109$ ). In addition, those who discontinued antihypertensive drugs had almost 14-fold increase in the risk to be hypertensive relative to subjects who never take antihypertensive drugs (adjusted $O R=14.16 ; 95 \% C I=7.14-28.05)$. In general, the results of this study is similar with our last year study which used different subjects. This study concluded that special attention should be taken to the elderly aged 40 years and over, to some one who discontinued antihypertensive drugs; and whom had light daily working load to prevent hypertension. (Med J Indones 2001; 10: 224-9)
\end{abstract}

Keywords: hypertensive, risk factor, adjusted odds ratio, elderly.

Hypertension is increasing in urban as well as in rural areas. However, governmental programs are still focusing on infectious diseases, and there is no comprehensive community programs to prevent degenerative diseases such as hypertension. ${ }^{1}$

\footnotetext{
- Department of Community Medicine, Faculty of Medicine, University of Indonesia, Jakarta, Indonesia

${ }^{+}$Department of Physiology, Faculty of Medicine, University of Indonesia, Jakarta, Indonesia
}

The estimated prevalence of hyertension ranges from $5 \%$ to $15 \%$ among population aged 20 years or over. $^{2,3}$ The recent study in Jakarta in 2000 revealed that the prevalence of hypertension was $30 \%$ (personal communication, MONICA report).

At present, Indonesia has about 215 million population and $70 \%$ of them live in rural area, ${ }^{1}$ it is estimated that in Indonesian rural community a big number of hypertensive people can be found. Some of 
them have stage 2 or 3 hypertension. On the other hand, few rural community-based hypertensive studies have been conducted to identify the risk factors related to hypertension in rural area.

Our previous report based on 490 subjects revealed some risk factors that were related to hypertension, i.e. age, body postures, daily working load, and past hypertensive medication. ${ }^{4}$ Since every year the second year medical students have to participate in a rural study, we conducted a study to reveal risk factors related to hypertension, in order to gain an additional information on some risk factors related to hypertension in a rural community.

\section{METHODS}

This study used a part of the data collected in the field study of the second year medical students of the Faculty of Medicine, University of Indonesia, Jakarta. The field study was conducted among the Sundanese ethnic group in a rural area, in Cijeruk subdistrict of Bogor regency, about $90 \mathrm{~km}$ southern of Jakarta, on June $27^{\text {th }}, 2001$.

We selected randomly 7 out of 18 villages. For each selected village, afterward we selected 1 hamlet and for each hamlet we selected 2 neighborhoods which were different from the year 2000 hypertensive study. People aged 18 years or above in each selected neighborhood were invited to participate in this study. For each neighborhoods, we listed the first 50 subjects who were willing to participate in this study.

Interviews and blood pressure measurements were conducted at the houses of the subjects by the 188 specially trained second year medical students. Each students interviewed and took the blood pressure of 34 subjects. The medical students were under close supervision of faculty members of the Faculty of Medicine, University of Indonesia. Each faculty member supervised 6-8 medical students.

The interview used a special questionnaire form. The information collected was demographic characteristics (gender, age, education, job, housing condition, and working load). Furthermore, additional data about the last six month habits in drinking coffee, eating, eating traditional vegetables and fruits to control hypertension, smoking, and sport. In addition, data about the current and past history of subject's illness (hyper- tension, kidney disease, diabetes mellitus, thyroid disease), hormonal contraceptive use, antihypertensive drugs consumption, and body posture were collected.

The time for measuring blood pressure was from 1:00 PM to 4:00 PM. Blood pressure measurements were done using mercury sphygmomanometer by the following techniques: ${ }^{5}$ the subject was seated in a chair with his/her back supported and his/her arms supported at heart level. Subjects were refrained from smoking and ingesting caffeine during the 30 minutes preceding the measurement. Measurement began after at least 5 minutes of rest. Both arms' systolic blood pressures (SBP) and diastolic blood pressure (DBP) were recorded. The SBP was recorded at the first appearance of sound (phase 1), and the disappearance of sound (phase 5) was used to define diastolic blood pressure (DBP). If the SBP was $140 \mathrm{~mm} \mathrm{Hg}$ or more, the measurement was repeated after about 5 minutes.

In this analysis we only analyzed the subjects having normal blood pressure, and stage 2 and 3 hypertension in order to identify some risk factors related to stage 2 or 3 hypertension. Therefore, the subjects who were taking antihypertensive drugs were excluded from this study.

The criteria for blood pressure classification were as follows. ${ }^{5}$ Blood pressure was regarded normal or optimal when systolic blood pressure was less than $130 \mathrm{~mm} \mathrm{Hg}$ and diastolic blood pressure was less than $85 \mathrm{~mm} \mathrm{Hg}$. In this analysis we regarded the normal and optimal blood pressure as normal blood pressure. High normal pressure and stage 1 hypertension was diagnosed when systolic blood pressure was 130-139 $\mathrm{mmHg}$ and $140-159 \mathrm{mmHg}$ or diastolic blood pressure was $85-89 \mathrm{mmHg}$ and $90-99 \mathrm{mmHg}$, respectively. Stage 2 hypertension was diagnosed when systolic blood pressure was 160-179 $\mathrm{mmHg}$, or diastolic blood pressure was $100-109 \mathrm{mmHg}$, while stage 3 hypertension was diagnosed when systolic blood pressure was $180 \mathrm{mmHg}$ or more, or diastolic blood pressure was $110 \mathrm{mmHg}$ or more.

The criteria for daily working loads were as follows: light daily working load if in general the tasks could be done in sitting or standing position, such as in clerks, house hold activities; moderate daily working load if the tasks resulted in an increase in breathing frequencies or sweating, such as in barbers; and heavy working load if the tasks needed muscles' activity 
which always resulted in the increase in both breathing frequencies and sweating, such as in blue color labor. ${ }^{5}$ Body postures (normal, skinny, and obese) were judged based on perception of the students who examined the subjects.

Statistical analyses were done using STATA 6.0 software. ${ }^{6}$ A number of risk factors were examined whether they were potential confounders and/or effect modifiers. Unconditional logistic regression analysis ${ }^{8}$ was used in order to determine the confounding effects and to determine the risk factors for hypertension. A risk factor was considered to be a potential confounder if in the univariate test it had a $P$-value $<0.25$ which would be considered as a candidate for the multivariate model along with all known risk factors for hypertension. ${ }^{7}$ Confounders were estimated by the method of maximum likelihood. Ninety-five percent confidence intervals were based on the standard error of coefficient estimates. Relative risks represented by odds ratios (OR) were estimated by the methods of maximum likelihood.

\section{RESULTS}

A number of 635 subjects participated in this study. For this study, 38 subjects who were taking antihypertensive drugs, 86 subjects with high normal hypertension, and 133 subjects with stage 1 hypertension were excluded. There were 269 subjects with normal blood pressure and 109 subjects with stage 2 or 3 hypertension who were included in this analysis.

Table 1 shows that hypertensive and normal blood pressure subjects were similarly distributed with respect to gender, profession, and housing condition. However, hypertensive subjects were more likely to be older compared to normal blood pressure subjects.

Table 1. Some demographic characteristic of subjects and risk of hypertension

\begin{tabular}{|c|c|c|c|c|c|c|}
\hline & \multicolumn{2}{|c|}{$\begin{array}{c}\text { Normal } \\
(\mathrm{N}=269)\end{array}$} & \multicolumn{2}{|c|}{$\begin{array}{l}\text { Hypertension } \\
(\mathrm{N}=109)\end{array}$} & \multirow{2}{*}{$\begin{array}{l}\text { Crude odds } \\
\text { ratio }\end{array}$} & \multirow{2}{*}{$\begin{array}{l}95 \% \text { confidence } \\
\text { intervals }\end{array}$} \\
\hline & $\mathrm{n}$ & $\%$ & $\mathrm{n}$ & $\%$ & & \\
\hline \multicolumn{7}{|l|}{ Gender } \\
\hline Male & 83 & 30.9 & 34 & 31.2 & 1.00 & Reference \\
\hline Female & 186 & 69.1 & 75 & 68.8 & 0.98 & $0.61-1.59$ \\
\hline \multicolumn{7}{|l|}{ Age group (years) } \\
\hline $18-39$ & 156 & 58.0 & 21 & 19.3 & 1.00 & Reference \\
\hline $40-49$ & 49 & 18.2 & 16 & 14.7 & 2.43 & $1.17-5.01$ \\
\hline $50-54$ & 15 & 5.6 & 15 & 13.8 & 2.43 & $3.18-17.35$ \\
\hline $55-59$ & 14 & 5.2 & 16 & 14.7 & 8.49 & $3.53-19.86$ \\
\hline $60-64$ & 16 & 5.9 & 20 & 18.3 & 9.29 & $4.17-20.66$ \\
\hline $65-84$ & 19 & 7.1 & 21 & 19.3 & 8.21 & $3.80-17.73$ \\
\hline \multicolumn{7}{|l|}{ Marital status } \\
\hline Married & 229 & 85.1 & 82 & 75.2 & 1.00 & Reference \\
\hline Unmarnied & 14 & 5.2 & 2 & 1.8 & 0.40 & $0.09-1.79$ \\
\hline Divorced & 3 & 1.1 & 0 & 0 & N/A & - \\
\hline Widow & 21 & 7.8 & 22 & 20.2 & 2.93 & $1.53-5.60$ \\
\hline Widower & 2 & 0.7 & 3 & 2.8 & 4.19 & $0.69-25.52$ \\
\hline \multicolumn{7}{|l|}{ Education } \\
\hline Illiterate/read only & 82 & 30.5 & 51 & 46.8 & 1.00 & Reference \\
\hline Primary school & 124 & 46.1 & 39 & 35.8 & 0.51 & $0.31-0.84$ \\
\hline Junior high school & 28 & 10.4 & 9 & 8.3 & 0.51 & $0.23-1.18$ \\
\hline Senior high school & 26 & 9.7 & 9 & 8.3 & 0.56 & $0.24-1.28$ \\
\hline College/university & 9 & 3.3 & 1 & 0.9 & 0.18 & $0.02-1.45$ \\
\hline \multicolumn{7}{|l|}{ Profession } \\
\hline None & 150 & 55.8 & 65 & 59.6 & 1.00 & Reference \\
\hline Laborer & 43 & 16.0 & 13 & 11.9 & 0.69 & $0.35-1.38$ \\
\hline Vendor/self employment & 37 & 13.8 & 16 & 14.7 & 0.99 & $0.52-1.92$ \\
\hline Employee & 14 & 5.2 & 5 & 4.6 & 0.82 & $0.29-2.38$ \\
\hline Others & 25 & 9.3 & 10 & 9.2 & 0.92 & $0.42-2.03$ \\
\hline \multicolumn{7}{|l|}{ Housing condition } \\
\hline Emergency & 11 & 4.1 & 3 & 2.8 & 1.00 & Reference \\
\hline Semi permanent & 47 & 17.5 & 14 & 12.8 & 1.09 & $0.27-4.47$ \\
\hline Permanent & 211 & 78.4 & 92 & 84.4 & 1.60 & $0.44-5.87$ \\
\hline
\end{tabular}

$\mathrm{N} / \mathrm{A}=$ not applicahle 
Hypertensive subjects were more likely to be widows or widowers compared to normal blood pressure subjects. On the other hands, hypertensive subjects were less likely to be married and unmarried.

In this analysis we could not prove that smoking habit increased the risk of hypertension. In addition, there was no evidence that those who for the last 6 months had the habit to have regular sport, or to drink coffee, had a lower risk of hypertension compared with those who had not (Table 2).

Table 2. Smoking, daily habits and risk of hypertension

\begin{tabular}{|c|c|c|c|c|c|c|}
\hline & \multicolumn{2}{|c|}{$\begin{array}{l}\text { Noimal } \\
(\mathrm{N}=269)\end{array}$} & \multicolumn{2}{|c|}{$\begin{array}{l}\text { Hypertension } \\
(\mathrm{N}=109)\end{array}$} & \multirow{2}{*}{$\begin{array}{l}\text { Crude } \\
\text { odds } \\
\text { ratio }\end{array}$} & \multirow{2}{*}{$\begin{array}{c}95 \% \\
\text { confidence } \\
\text { intervals }\end{array}$} \\
\hline & $\mathrm{n}$ & $\%$ & $\mathrm{n}$ & $\%$ & & \\
\hline \multicolumn{7}{|l|}{ Smoking } \\
\hline Never & 174 & 64.7 & 70 & 64.2 & 1.00 & Reference \\
\hline Past & 15 & 5.6 & 11 & 10.1 & 1.82 & $0.80-4.16$ \\
\hline Current & 80 & 29.7 & 28 & 25.7 & 0.87 & $0.52-1.45$ \\
\hline \multicolumn{7}{|l|}{ Sport } \\
\hline Never & 160 & 59.5 & 61 & 56.0 & 1.00 & Reference \\
\hline Past & 37 & 13.8 & 15 & 13.8 & 1.06 & $0.54-2.07$ \\
\hline Current & 72 & 26.8 & 33 & 30.3 & 1.20 & $0.72 \cdot 2.00$ \\
\hline \multicolumn{7}{|c|}{ Daily working load } \\
\hline Light & 61 & 22.7 & 37 & 33.9 & 1.00 & Reference \\
\hline Moderate & 155 & 57.6 & 60 & 55.0 & 0.64 & $0.38-1.06$ \\
\hline Heavy & 53 & 19.7 & 12 & 11.0 & 0.37 & $0.18-0.79$ \\
\hline \multicolumn{7}{|c|}{ Drinking cofee per week } \\
\hline Almost never & 122 & 45.4 & 46 & 42.2 & 1.00 & Reference \\
\hline $\begin{array}{l}\text { Less than one } \\
\text { time }\end{array}$ & 18 & 6.7 & 10 & 9.2 & 1.47 & $0.63-3.43$ \\
\hline 1 - 2 times & 22 & 8.2 & 14 & 12.8 & 1.69 & $0.80-3.58$ \\
\hline 3 - 4 times & 14 & 5.2 & 4 & 3.7 & 0.76 & $0.24-2.42$ \\
\hline Almost everyday & 93 & 34.6 & 35 & 32.1 & 1.00 & $0.60-1.67$ \\
\hline \multicolumn{7}{|c|}{ Salty fish per week } \\
\hline Almost never & 13 & 4.8 & 13 & 11.9 & 1.00 & Reference \\
\hline $\begin{array}{l}\text { Less than one } \\
\text { time }\end{array}$ & 7 & 2.6 & 4. & 3.7 & 0.57 & $0.13-2.43$ \\
\hline $1-2$ times & 25 & 9.3 & 16 & 14.7 & 0.64 & $0.24-1.73$ \\
\hline $3-4$ times & 22 & 8.2 & 6 & 5.5 & 0.27 & $0.08-0.89$ \\
\hline Almost everyday & 202 & 75.1 & 70 & 64.2 & 0.34 & $0.15-0.78$ \\
\hline
\end{tabular}

Table 3 shows that hypertensive subjects were more likely to be those who were taking cucumber everyday, or less than one time per week consumed morinda (Table 3). Relative to those who were almost never consumed cucumber, subject who were taking cucumber 1-2 and 3-4 time a week had an increase risk to be hypertensive 2.7 and 3 folds respectively. In addition, compared to those who almost never took star fruit, subject who consumed 1-2 times a week had almost a 2 fold increase in the risk of hypertension.
Table 3. Traditional medicine intake, eating habits, and risk of hypertension

\begin{tabular}{|c|c|c|c|c|c|c|}
\hline & \multicolumn{2}{|c|}{$\begin{array}{l}\text { Normal } \\
(\mathrm{N}=269)\end{array}$} & \multicolumn{2}{|c|}{$\begin{array}{l}\text { Hypertension } \\
(\mathrm{N}=109)\end{array}$} & \multirow{2}{*}{$\begin{array}{l}\text { Crude } \\
\text { odds } \\
\text { ratio }\end{array}$} & \multirow{2}{*}{$\begin{array}{c}95 \% \\
\text { confidence } \\
\text { intervals }\end{array}$} \\
\hline & $\mathrm{n}$ & $\%$ & $\mathrm{n}$ & $\%$ & & \\
\hline \multicolumn{7}{|l|}{ Garlic per week } \\
\hline Almost never & 16 & 5.9 & 7 & 6.4 & 1.00 & Reference \\
\hline $\begin{array}{l}\text { Less than one } \\
\text { time }\end{array}$ & 11 & 4.1 & 3 & 2.8 & 0.62 & $0.13-2.95$ \\
\hline 1- 2 times & 12 & 4.5 & 9 & 8.3 & 1.71 & $0.50-5.92$ \\
\hline 3 - 4 times & 9 & 3.3 & 7 & 6.4 & 1.78 & $0.47-6.91$ \\
\hline Almost everyday & 221 & 82.2 & 83 & 76.1 & 0.88 & $0.34-2.16$ \\
\hline \multicolumn{7}{|c|}{ Cucumber per week } \\
\hline Almost never & 41 & 15.2 & 7 & 6.4 & 1.00 & Reference \\
\hline $\begin{array}{l}\text { Less than one } \\
\text { time }\end{array}$ & 45 & 16.7 & 14 & 12.8 & 1.82 & $0.66-4.96$ \\
\hline 1 - 2 times & 76 & 28.3 & 35 & 32.1 & 2.70 & $1.10-6.61$ \\
\hline 3 - 4 times & 51 & 19.0 & 26 & 23.9 & 2.99 & $1.18-7.57$ \\
\hline Almost everyday & 56 & 20.8 & 27 & 24.8 & 2.82 & $1.12-7.11$ \\
\hline \multicolumn{7}{|c|}{ Star fruit per week } \\
\hline Almost never & 154 & 57.2 & 57 & 52.3 & 1.00 & Reference \\
\hline $\begin{array}{l}\text { Less than one } \\
\text { time }\end{array}$ & 81 & 30.1 & 32 & 29.4 & 1.07 & $0.64-1.78$ \\
\hline 1 - 2 times & 23 & 8.6 & 16 & 14.7 & 1.88 & $0.93-3.81$ \\
\hline 3 - 4 times & 7 & 2.6 & 1 & 0.9 & 0.39 & $0.05-3.20$ \\
\hline Almost everyday & 4 & 1.5 & 3 & 2.8 & 2.03 & $0.44-9.33$ \\
\hline \multicolumn{7}{|l|}{ Morinda per week } \\
\hline Almost never & 235 & 87.4 & 83 & 76.1 & 1.00 & Reference \\
\hline $\begin{array}{l}\text { Less than one } \\
\text { time }\end{array}$ & 17 & 6.3 & 16 & 14.7 & 2.66 & $1.29-5.51$ \\
\hline 1 - 2 times & 10 & 3.7 & 7 & 6.4 & 1.98 & $0.73-5.38$ \\
\hline $3-4$ times & 3 & 1.1 & 0 & 0.0 & N/A & - \\
\hline Almost everyday & 4 & 1.5 & 3 & 2.8 & 2.12 & $0.47-9.69$ \\
\hline
\end{tabular}

N/A = not applicable

Furthermore, in this study there was no evidence that subject's history of diseases (kidney, diabetes mellitus, thyroid) increased the risk of hypertension (Table 4).

Table 4. History of some diseases and risk of hypertension

\begin{tabular}{|c|c|c|c|c|c|c|}
\hline & \multicolumn{2}{|c|}{$\begin{array}{l}\text { Normal } \\
(\mathrm{N}=269)\end{array}$} & \multicolumn{2}{|c|}{$\begin{array}{l}\text { Hypertension } \\
(\mathrm{N}=109)\end{array}$} & \multirow{2}{*}{$\begin{array}{l}\text { Crude } \\
\text { odds } \\
\text { ratio }\end{array}$} & \multirow{2}{*}{$\begin{array}{c}95 \% \\
\text { confidence } \\
\text { intervals }\end{array}$} \\
\hline & $\mathrm{n}$ & $\%$ & $\mathrm{n}$ & $\%$ & & \\
\hline \multicolumn{7}{|l|}{ Kidney } \\
\hline Never & 239 & 88.8 & 96 & 88.1 & 1.00 & Reference \\
\hline Past & 7 & 2.6 & 4 & 3.7 & 1.42 & $0.41-4.97$ \\
\hline Current & 4 & 1.5 & 1 & 0.9 & 0.62 & $0.07-5.64$ \\
\hline Unknown & 19 & 7.1 & 8 & 7.3 & 1.04 & $0.44-2.47$ \\
\hline \multicolumn{7}{|c|}{ Diabetes mellitus } \\
\hline Never & 259 & 96.3 & 105 & 96.3 & 1.00 & Reference \\
\hline Past & 0 & 0 & 0 & 0 & N/A & - \\
\hline Current & 0 & 0 & 0 & 0 & N/A & - \\
\hline Unknown & 10 & 3.7 & 4 & 3.7 & 0.99 & $0.30-3.22$ \\
\hline \multicolumn{7}{|l|}{ Thyroid } \\
\hline Never & 258 & 96.3 & 106 & 97.2 & 1.00 & Reference \\
\hline Past & 3 & 3.7 & 1 & 0.9 & 0.81 & $0.08-7.89$ \\
\hline Current & 2 & 95.9 & 0 & 0 & N/A & - \\
\hline Unknown & 6 & 2.2 & 2 & 1.8 & 0.81 & $0.16-4.08$ \\
\hline
\end{tabular}


Our final model on the relationship between some risk factors and hypertension was shown on Table 5. This model indicates that subjects aged 40 years or over had an increased risk to be hypertensive compared with the subjects aged 18-39 years. The age group who had the most prominent hypertensive risk was the age group of 55-59 years. This age group had almost 18 -folds increase in the risk to be hypertensive (adjusted odds ratio $(\mathrm{OR})=17.73 ; 95 \%$ confidence intervals $(\mathrm{CD})=6.26-50.27)$. The older sub-groups, 60-64 years and 65-84 years had a 9 folds and almost 11 folds increase in the risk to be hypertensive, respectively.

Compared to normal body posture subjects, those who were obese had a moderate increase in the risk to be hypertensive $($ adjusted $\mathrm{OR}=1.90 ; 95 \% \mathrm{CI}=0.87$ 4.17; $\mathrm{P}=0.109$ ). However, the skinny subjects had a moderate increase in the risk to be hypertensive (adjusted $\mathrm{OR}=0.62 ; \mathrm{P}=0.188$ ). Compared to subjects who had light daily working load, those who had heavy daily working load had a $72 \%$ decrease in the risk to be hypertensive (adjusted $\mathrm{OR}=0.28 ; 95 \%$ $\mathrm{CI}=0.10-0.74$ ).

Additionally, those who discontinued antihypertensive drugs had almost 14 folds increase in the risk to be hypertensive relative to subjects who never take antihypertensive drugs (adjusted $\mathrm{OR}=14.16 ; 95 \% \mathrm{CI}=$ $7.14-28.05)$.

Table 5. Relationship between age group, body posture, daily working load, past hypertension medication and risk of hypertension

\begin{tabular}{|c|c|c|c|c|c|c|}
\hline & \multicolumn{2}{|c|}{$\begin{array}{c}\text { Normal } \\
(\mathrm{N}=269)\end{array}$} & \multicolumn{2}{|c|}{$\begin{array}{c}\text { Hypertension } \\
(\mathrm{N}=109)\end{array}$} & \multirow{2}{*}{$\begin{array}{l}\text { Adjus- } \\
\text { ted } \\
\text { odds } \\
\text { ratio* }\end{array}$} & \multirow{2}{*}{$\begin{array}{c}95 \% \\
\text { confidence } \\
\text { intervals }\end{array}$} \\
\hline & $n$ & $\%$ & $\mathrm{n}$ & $\%$ & & \\
\hline \multicolumn{7}{|c|}{ Age group (years) } \\
\hline $18-39$ & 156 & 58.0 & 21 & 19.3 & 1.00 & Reference \\
\hline $40-49$ & 49 & 18.2 & 16 & 14.7 & 3.13 & $1.31-7.46$ \\
\hline $50-54$ & 15 & 5.6 & 15 & 13.8 & 8.69 & $3.21-23.49$ \\
\hline $55-59$ & 14 & 5.2 & 16 & 14.7 & 17.73 & $6.26-50.27$ \\
\hline $60-64$ & 16 & 5.9 & 20 & 18.3 & 9.03 & $3.27-24.93$ \\
\hline $65-84$ & 19 & 7.1 & 21 & 19.3 & 10.79 & $3.86-30.18$ \\
\hline \multicolumn{7}{|c|}{ Body posture } \\
\hline Normal & 148 & 55.0 & 53 & 48.6 & 1.00 & Reference \\
\hline Skinny & 86 & 32.0 & 32 & 29.4 & 0.62 & $0.31-1.26$ \\
\hline Obese & 35 & 13.0 & 24 & 22.0 & 1.90 & $0.87-4.17$ \\
\hline \multicolumn{7}{|c|}{ Daily working load } \\
\hline Light & 61 & 22.7 & 37 & 33.9 & 1.00 & Reference \\
\hline Moderate & 155 & 57.6 & 60 & 55.0 & 0.98 & $0.49-1.97$ \\
\hline Heavy & 53 & 19.7 & 12 & 11.0 & 0.28 & $0.10-0.74$ \\
\hline \multicolumn{7}{|c|}{ Past antihypertensive medication } \\
\hline Never & 249 & 92.6 & 49 & 45.0 & 1.00 & Reference \\
\hline Ever & 20 & 7.4 & 60 & 55.0 & 14.16 & $7.14-28.05$ \\
\hline
\end{tabular}

* Adjusted each other for variables listed on this table.

\section{DISCUSSION}

There are several limitations that must be considered in the interpretation of our findings. Our analysis is limited to several factors and no laboratory test was performed. This study was conducted in a rural area within three hours, and involving 188 medical students, therefore we did not able to provide enough weighting scales to measure body weight. In addition, the blood pressure were measured by second-year medical students who did not have enough experience in taking blood pressures in a community.

In spite of the these limitations, the second-year medical students had passed physiology class and had been specially trained for this study. In addition, they were supervised closely by the faculty members on sites when they measured blood pressures and interviewed the subjects.

The crude odds ratio analysis revealed that taking cucumber 1-4 times and and/or star fruit 1-2 times a week increases the risk of hypertension (Table 3). These traditional medications were strong enough to be included in the final model. However, this risk factors were not included on the final model. Most likely, afterward diagnosed to have hypertension the hypertensive subjects began to take cucumber and/or star fruits to control their hypertension. These conditions (taking cucumber 1-4 times and/or star fruit 1-2 times a week) were seen more in hypertensive subjects than normal blood pressure subjects.

Our final model showed that obesity were one of the risk factors for hypertension (Table 5). This finding is similar with our previous study ${ }^{4}$ and other studies in Indonesia, ${ }^{2,3}$ as well as in developed countries. ${ }^{5,9}$ However, at the same area where the study was conducted, some people considered that one of the benefit of being a family planning acceptors was gaining body weight. ${ }^{10}$ The poor rural people wanted to have an appearance of wealthy people, such as obesity. This misleading opinion need to be corrected in order to prevent hypertension.

In addition, the final results show that compared with those who had light daily working load, those with heavy daily working load had a better protection against hypertension. This finding is similar with the other ${ }^{2,5,9}$ and our previous studies. 
Our data also reveals that discontinuation of antihypertensive drugs increased the risk of hypertension 14 folds relative to those who never had any antihypertensive medication. These results is consistent with our previous study ${ }^{4}$ which indicated 12 folds increase in the risk to be hypertensive. Furthermore, this finding is similar with the findings of other studies. ${ }^{2,5,9}$ Therefore, hypertensive people need to be given counseling on hypertensive treatment to prevent discontinuation of medication in hypertensive subjects.

In term of gender and education level, there was no difference in the risk to be hypertensive, and these findings are in accordance with the findings of other studies in Indonesia. ${ }^{2,4,11}$

Our final model reveals that compared with the subjects aged 18-39 years, subjects aged 40 years or over had an increase risk to be hypertensive, and the risk was most prominent among the subjects aged 5559 years. The older age groups (60-64 years and 6584 years) had relatively decreased risk to be hypertensive. The present finding is in accordance with our previous study. ${ }^{4}$ This phenomena is analog to the healthy worker survivor effect. ${ }^{12}$ Those who have a better physical, mental, and other conditions had the ability to survive. In addition, some elder people (60 years or older) had been passed away of other diseases. Therefore, the older people who had better health condition were less likely to be hypertensive.

In conclusion, to prevent hypertension special attention should be paid to obese persons, elderly aged 40 years and over, and to whom discontinued antihypertensive drugs, or had light daily working load.

\section{Acknowledgment}

The authors thank all subjects, the local leaders, and second year medical students of the Faculty of Medicine, University of Indonesia, who cooperatively participated in this study. Special thanks to the Faculty members who were in charge as on site field supervisors for their high dedication. And lastly, to Dr. Jeanne A. Pawitan PhD to review the earlier drafts of this manuscript that improved the final product.

\section{REFERENCES}

1. Ministry of Health of the Republic of Indonesia. Health profile on Indonesia 2000. Jakarta: The Ministry; 2001.

2. Boedi-Darmojo R. Epidemiology of hypertensive in Indonesia. In: Boedi-Darmojo R, Ed. Boedi-Darmojo's Papers. Semarang: University of Diponegoro; 1994. p. 275-87.

3. Boedi-Darmojo R, Setianto B, Sutedjo, Kusmana D, Andradi, Supari F, et al. A study of baseline risk factor for coronary heart diseases. Results of population screening in a developing country. Rev Epidem et Sante Publ 1990; 38:487-91.

4. Basuki B, Setianto B. Age, body posture, daily working load, past hypertensive drug and risk of hypertension. Med $\mathrm{J}$ Indones 2001;1:29-33.

5. National Heart, Lung and Blood Pressure Institute. The sixth report of the joint national committee on prevention, detection, evaluation and treatment of high blood pressure. Nat Inst Hlth Publ No. 98-4084. Bethesda: The Institute; 1997.

6. Stata Corporation. Stata statistical software: Release 6.0. Texas: College station; 1999.

7. Breslow NE, Day NE. Statistical Methods in Cancer Research. Vol I. The analysis of case-control studies. IARC Sci Publ No.32. Lyon: International Agency for Research on Cancer; 1980.

8. Hosmer DW, Lemeshow S. Applied logistic regression. New York: John Willey \& Sons; 1989.

9. Frohlich ED. Hypertension. In: Pearson TA, Criqui MH, Lupker RV, Oberman A, Winston M, editors. Primer in prevention epidemiology. Dallas: American Heart Association; 1994.p.131-42.

10. Basuki B. Improvement system on contraceptive choice at Cijeruk sub district. Jakarta: National Family Planning Coordinating Board/The Population Council; 1996.

11. Jakarta Monica Team. Monica community hypertension pattern. In: Sutedjo, Setianto B, Boedi-Darmojo R, Editors. Presentation and discussion on Jakarta Monica II survey 1993. Jakarta: Center for National Health on Heart; 1994. p.78-98.

12. Arrighi HM, Hertz-Piciotto I. The evolving concepts of the healthy worker survivor effect. Epidemiol 1994;5:186-96. 